\title{
TARIFF REGIMES IN LATIN AMERICA: PRIVILEGES AND THE HISTORICAL EXPERIENCE OF CHILE AND PERU
}

\author{
[Celní režimy v Latinské Americe: Role privilegií a historická zkušenost Chile
} a Peru]

\author{
Martin Šárek ${ }^{1}$, Marek Vokoun ${ }^{2}$, Lourdes Daza Aramayo $^{3}$ \\ ${ }^{1}$ University of Economics, Faculty of International Relations, Prague, W. Churchill Sq. 1938/4, 13067 Prague 3 \\ Email:xsarm11@vse.cz \\ ${ }^{2}$ Institute of Technology and Business, Faculty of Corporate Strategy, Department of Management, Okružni 10, \\ 37001 České Budějovice \\ Email:marek.vokoun@mail.vstecb.cz \\ ${ }^{3}$ University of Economics, Faculty of International Relations, Prague, W. Churchill Sq. 1938/4, 13067 Prague \\ Email: lourdes.aramayo@vse.cz
}

\begin{abstract}
This paper focuses on the effects of the consistently enforced liberal policies in Chile of the last 40 years in comparison to the inconsistent policies of the Peruvian government during the same period. Tariff policy can be used as a representative indicator of the liberal/protective economic approach given how important openness is to trade in the long term development of small economies. The first section explains tariff and tariff policy. The second details the historical development of tariff policies in Chile and Peru and the third part contains a comparison of their current tariff structures. Both countries started at a similar point in the 1970s, both utilize comparable natural resources and have a similar GDP ratio. However, only Chile has become one of the most developed economies in the region while Peru, although progressing rapidly in the last decade, is still lagging 10 years behind due to inconsistent policies applied during the '70s and '80s. By turning to neoliberalism in the '90s, Peru laid the foundation for their current strong economic development and is now, in some ways, even more open than Chile with a few exceptions in the textile, coffee and beef industries to which Peru applies high tariff rates to protect the jobs these industries provide.
\end{abstract}

Keywords: Cascading tariff structure, Chile, Open trade policy, Peru, Uniform tariff structure.

JEL classification: F19

Doručeno redakci: 19.1.2016; Recenzováno: 19.2.2016; 3.3.2016; Schváleno k publikování: 24.8.2016

\section{Introduction}

This paper uses historical development in Chile and Peru with an aim to analyze economic and political phenomena associated with different tariff regimes in the region. It will explore and detect the optimal tariff policy for many of the small countries of Latin America. This interdisciplinary approach follows the interpretation of results based on simple principles and does not depend heavily on sophisticated neoclassical economic theories. Two countries, Chile and Peru, have been selected as benchmark economies for useful comparison and a consequent analysis of economic policies and current economic development.

After a critical review of historical and economic policy analyses of tariffs in the Latin American region, the paper has been organized into three sections. The first deals with the definitions of tariffs and subsequent economic policies, i.e. traditional and modern trade regulations. The next chapter deals with the historical development of Chile and Peru and identifies certain phenomena such as privilege and the economic reasoning of political leaders. The third section of the paper analyses the differences in the region based on a comparison of current tariffs. 
Chile and Peru are heterogeneous economies. To some extent it makes this analysis independent on the level of economic development, surmising that a reduction in tariffs in Latin America is a way to adapt to global tendencies faster and to better allocate scarce resources based on free market decisions rather than administrative economic policy privileges.

\section{Theoretical background}

Despite abundant natural resources and an advantageous starting position compared to North America, Latin America is currently a poorly performing part of the world, staggering behind advanced economies. This unfortunate development started during colonial times and worsened after gaining independence years of instability and civil wars. During the 19th century, the region stagnated in comparison to advanced countries and was hindered by import substitution policies in the 20th century (Edwards, 2009, p. 2-6). Various authors have different explanations for the underlying causes. Instability and late-gained independence account for a part of the current GDP gap between Latin American economies and the US (Przeworski \& Curvale, 2005, p. 12). Other factors had an impact as well. For example the historical development and the regressive effect of consequently introduced tariffs (BulmerThomas, 2003, p. 24-33) \& (Przeworski \& Curvale, 2005, p. 12). As Andersen and Babula (2008, p. 8) mention, there are two sources of economic growth; either faster accumulation of capital, or through increasing productivity by speeding up technological innovation which may be achieved through trade openness.

After the civil wars and turmoil finished around 1870, while Latin America experienced a long era of stability, it still did not exhibit the exceptional growth needed to bring the region closer to the economically advanced countries. In the twentieth century, their position got even worse, partly due to protective import substitution policies as Prados de la Escosura's (2007) research indicates (cited by Edwards, 2009, p. 3-5). These and many other factors, like elite-favoring institutions, placed Latin America in a developing but not developed position in the world economy. There are some success stories; however, one of them being Chile who, due to a military coup, was able to change the environment and directed the economy towards strong growth (Edwards, 2009, p. 16). After the junta's policies had been introduced, Chile experienced the second fastest average trade growth (8\%) in Latin America following Mexico (Monfort, 2008, p. 3). Chile, like Peru, focuses on the export of primary resources which, in 2000, accounted for similar share at $84 \%$ (Bulmer-Thomas, 2003, p. 9). Nevertheless, despite their similar starting positions, the responses of each country to the challenges of the end of the 20th century vary significantly.

Before exploring the differences and outcomes it is essential to first establish the definition of tariffs. Our working definition of tariffs is based on the recommendation of the OECD (Love \& Lattimore, 2009, p. 59) which defines tariffs as norms and taxes which are imposed upon goods crossing borders (foreign goods). This definition is clearly cut and a traditional tariff structure can be studied as well as new regulations which consist of administrative burden, need of specific certification and standards. This paper is more oriented on the traditional tariff structure and, while the administrative burden is not the same across the LA region, our benchmark countries represent economies with rather low to average administrative burdens ${ }^{1}$ which likely makes the results slightly underestimated. In the historical analysis section, we

\footnotetext{
${ }^{1}$ The lead time to import was 1 day in Chile and 2 days in Peru in 2014, in the region the average is 3.1 days. Source: World Bank and Turku School of Economics, Logistic Performance Index Surveys. Data is available online at: http://www.worldbank.org/lpi
} 
are going to mix the definitions of tariffs, duties and trade economic policies to some extent because not all cited authors use the OECD approach.

The definition of tariff is not very clearly established among various authors and institutions. Definitions depend on whether these are theoretical definitions (capturing the purpose of tariffs), or more practically oriented legislative definitions which define tariffs for fiscal purposes (defining the situation under which the requirement to pay duties arises). To understand tariffs more, it would be appropriate to explore the origins and historical development of the term.

Tariff in its earliest form originated from trade and transport fees, most commonly fees for the use of ports, trade routes, bridges, etc. Another example of a tariff could be the fee a merchant paid to get entry to certain areas or payment for receiving protection of his/her goods on markets, which is still used nowadays in the form of rent/fee for using a sales area (Šterrbová, Černá, Čajka \& Bolotov, 2013, p. 110). According to Bakeš (2012, p. 290-291), it is essential to differentiate fees paid for the use of private roads, bridges or fords, called tolls, from tariffs. A tariff is a public fee. Matoušek \& Sabelová (2007, p. 3-4) specify and distinguish these two terms by the subject of the charge and the method of transportation. A toll is linked to the route taken (roads, bridges, etc.) while a tariff is linked directly to the goods transported. Thus, tariffs derived from the price of goods and from the type of goods involved. However, over time, these two terms began to fuse into a single meaning - a duty. A tariff; therefore, most resembles sales (or excise) tax which is linked to price and, in some cases, to the type of goods. Love \& Lattimore (2009, p. 56) define a tariff simply as a tax on foreign goods. Similarly, tariffs are perceived by Bakeš $(1979$, p. 102) as the statutory compulsory payment linked to the transfer of goods across borders levied either from the importer, exporter or ultimate consignee of the goods.

Another definition is provided by the European Union which, according to the Community Customs Code, divides tariffs into two groups - import duties and export duties. These are defined as "customs duties and charges having an effect equivalent to customs duties payable on the importation of goods, agricultural levies and other import charges introduced under the common agricultural policy or under the specific arrangements applicable to certain goods resulting from the processing of agricultural products." (Council Regulation (EEC) No 2913/92, 1992). Definition of export duties differs only by replacing the word import with the word export. Therefore, according to the Customs Code, both types of duties include not only fees for import/export of goods, but also specifically fees linked to the common agricultural policy.

An interesting definition of tariffs was provided by the Constitutional Court of Czech Republic which, in its judgment 643/06 of 13. 9.2007 (2007), perceives duty as a form of indirect taxation, specifically a consumption tax. The Constitutional Court cites A. Nováček (n. d., p. 493) and his definition of duty as a public tax, bringing revenue to the state budget, at the same time pursuing various objectives (resp. interests), such as financial interests or those of the national economy. Later definitions focused on establishing the subject of customs duties or approached tariffs from a fiscal point of view as a government budget resource. However, they should not only be seen as a fiscal resource, but also as a tool through which a government can influence its international trade policy. The monetary purpose of tariffs thus becomes only one of various government policies linked to tariffs and not necessarily the most important. Štěrbová, Černá, Čajka \& Bolotov (2013, p. 110) define duties as previously announced rates set for a certain period of time which belong to 
government tariff instruments. These rates are established through law regulation by which a government affects its trade policy. The expression "tariff" may also be used to describe tools that do not comply with the aforementioned characteristics (eg. rates set only for a certain period of time). If that is the case, these are non-tariff tools and not actual tariffs (Šterrbová, Černá, Čajka \& Bolotov, 2013, p. 110). In addition, tariff's fiscal and foreign trade roles can also be used to protect the domestic market, according to Klabouchová (1995, p. 5).

Tariff policy thus pursues a variety of interests which can be divided into three main groups; fiscal function, international trade function and domestic market protection. International trade objectives of the government can be associated with other macroeconomic goals such as achieving a certain level of employment or an effort to create pressure on domestic companies, pushing them to innovate and improve productivity, thus leading to higher tax returns and an overall increase of welfare. Tariff policy can then be understood as a tool of other government policies.

\section{Historical development of Chile and Peru}

In this section, the optics of international trade economic policy are used to analyze recent economic development in Chile and Peru. The analysis of the economic reasoning of political leaders in Chile and Peru is of particular interest. The data and sources used for this economic historical analysis are:

- World bank statistics, World trade organization statistics, SUNAT, OECD

- American Economic Association, Journal of Eastern Europe Research in Business and Economics, Journal of Competition Law and Policy, Latin American Research Review

- Latin American Studies Association, Institute of Latin American Studies University of Texas

- Review of FTA between Peru and China

- New York Times, Los Angeles Times, The Oxford Analytica Daily Brief Service

Figure 1: Real GDP per capita of Chile and Peru between 1966 and 2014

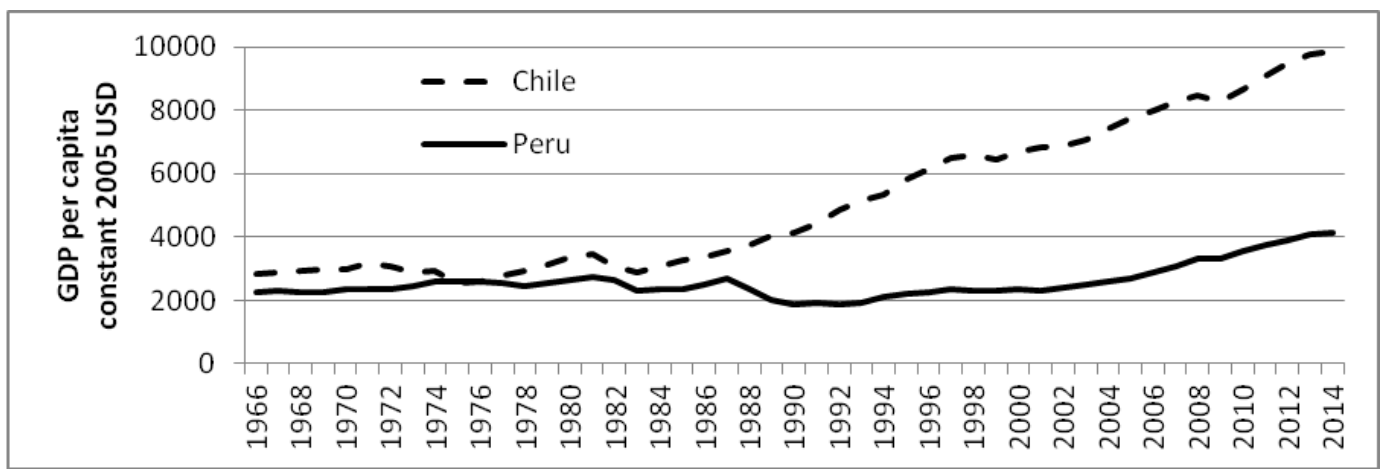

Source: World Bank National Accounts Data and OECD National Accounts Data Files: GDP per capita [online] [accessed 3. December 2015]. Accessible from: data.worldbank.org/indicator/NY.GDP.PCAP.KD

Our analysis starts in the 1970s. Both economies were comparable in terms of their level of economic development (Figure 1). Juan Velasco Alvarado assumed executive power in Peru in 1968. His administration, called a "military junta" was represented by economic policy which favored domestic production through import-substitution and high tariff rates (Conaghan, Malloy and Abugattas, 1990, p. 6). In the same period, Salvador Allende assumed executive power in Chile in 1970. His administration was represented by the Popular Front a combination of communists and socialists. Its main goal was to create a socialist economy through a series of economic reforms and confiscation (Žídek, 2004, p. 226). The Popular 
Front tried to steer the Chilean economy toward autocracy, specifically through an importsubstitution policy, during which the average tariff rose to $105 \%$ and tariffs on some items exceeded $750 \%$ (Meller, 1993). In addition to these measures, the government imposed restrictions and quotas on imports (Meller, 1992, p. 4). The consequence of this restrictive trade policy was the reduction in effectiveness of domestic companies which were not exposed to pressure from foreign companies and had very few incentives to increase their productivity and innovate. This situation was beneficial to manufacturers represented by lobby groups which became more influential and wished to preserve their status (Žídek, 2004, p. 228). Corbo (1997, p. 74) cites Paul Krugman (1993) who defines these groups as iron triangles - companies dependent on protectionist measures (inefficient and free market noncompetitive companies), a labor force which works for higher wages than would be achieved in an open economy, and officials who have control over the system and profit from it. Corbo (1997, p. 74) moreover mentions "happy" importers who gained the privilege to import in this protectionist system.

\section{Privileges in the 1970s - reduce or not to reduce?}

The poor economic development in the 1970s led to changes in power and the reasoning of the winning parties and leaders was based on the reduction of privileges. In Peru, privileges were applied and lasted until the end of the period, while Chile reduced the monopolistic privileges of the status quo interest groups. The collapse of the Chilean economy resulted in a military coup led by General Pinochet in 1973. He started to implement radical changes and headed back to a market economy, greatly reducing the influence of the government on market processes. The junta generals decided to reduce prohibitive tariff rates to a lower level and, mainly due to weak lobby groups and their non-existent links to the new military government, decided to establish a uniform tariff which would not favor any industry or interest group (Pastor \& Wise, 1992, p. 83) (Žídek, 2004, p. 229). Pinochet's government's reasoning behind the removal of trade barriers, lowering of prohibitive tariff levels and opening the economy to foreign competition was the opinion that the protectionist policies set by previous governments had led to the monopolization of the economy and lower effectiveness of companies - with the outcome strongly affecting the small Chilean economy (Cobro, 1997, p. 74). The junta-proposed transition into a transparent environment took place in three phases. In the first phase, they focused on removing prohibitive tariffs and an overall reduction of high tariffs. Tariff rates became the most significant obstacle to trade, due to the previous elimination of non-tariff measures. The highest rates were reduced from $750 \%$ (1973) to $129 \%$ in 1975 . The average tariff rate fell from $105 \%$ to $57 \%$, while some rates were increased in order to reduce the effective rate of protection (Corbo 1997, p. 74).

In the second phase (1975), a cascading tariff structure ranging from 10 to $35 \%$ was set. The highest rates favored manufacturers of processed industrial and consumer goods, but discriminated against producers of raw materials and basic products with low added value, giving them a lower level of protection. The average tariff level at this stage dropped to $19.7 \%$, more than halving those achieved in the previous phase (Corbo, 1997, p. 75). After the introduction of the cascading structure, those producers who were protected by the lowest rates (manufacturers of products with lower added value), who saw no reason to be discriminated against, started pushing for a uniform tariff rate. Some Chilean economists, however, perceived the cascade structure as having a positive impact on industrial production and saw it as a better way of dealing with market failures (Corbo, 1997, p. 75). Nevertheless, these opinions did not change the decision of the Ministry of Finance, which in December 1977 decided that it would gradually introduce a uniform 10\% tariff rate. That was achieved after a year and a half (1979) when the rate stabilized at 10\%. However, this rate lasted only a 
few years as a result of the crisis linked to the increase of interest rates in the United States (Corbo, 1997, p. 75).

The significance of the change carried out by Pinochet's government can be demonstrated by the Commercial Reform Index introduced by Morley (Paus, Reinhardt \& Robinson, 2003, p. 5). The Index ranges from 0 to 1 ; the higher the value, the more open to trade the economy is. In 1970 Chile scored 0.126 ranking as one of the most protectionist countries in the region. In 1980, 7 years after the coup, Chile was the most open to trade scoring 0.974. In comparison, Peru, during the 1970s scored 0.507 on average (Paus, Reinhardt \& Robinson, 2003, p. 5-10).

\section{Privileges in the 1980s - The role of independent economic policy and consistency}

Political representation in Peru was aware of certain economic accomplishments in Chile with regards to a cascading tariff structure and wide tariff reduction (Corbo, 1997, p. 65). The open trade policy and tariff reduction in South American countries had a positive impact on labor productivity growth in the region during the '70s, '80s and '90s (Paus, Reinhardt \& Robinson, 2003). The study of 7 South American countries and 27 industries also unveiled a mutual causal link between export and productivity growth during that period (Paus, Reinhardt \& Robinson, 2003).

The Peruvian imitation process was hoped to bring an economic boom and stability. This economic policy was partially enforced by the IMF, along with other reforms required to obtain the finances needed to cover debt payments (Pastor \& Wise, 1992, p. 86-89). However, the imitation process differed substantially. In Chile, the power was in the hands of a military junta and economic policy was, to some extent, adapting consistently. On the other hand, it was extreme and inconsistent in Peru (Pastor \& Wise, 1992, p. 83). In other words, the Peruvian imitation process failed because they lacked the know-how and introduced inconsistent economic policies. The process in Peru was to some extent independent of "tariffs status quo" interest parties because, on average, the level of tariffs decreased substantially. The failure was one of inconsistency and lack of experience combined with neoliberal monetary and economic policy. Having failed attempts to govern economy through state intervention in the '70s, there was a swing towards a more liberal and open economy which lasted from 1980 till 1985 (Pastor \& Wise, 1992, p. 83-85).

The new government under Belaúnde decided to follow a more transparent approach, abandoning subsidies and supporting a return to the traditional sectors where Peru had its comparative advantage (Pastor and Wise, 1992, p. 89).

Alongside the decline in tariff rates, approximately $98 \%$ of the goods could be imported without any restriction which, together with the decrease in tariff rates, led to a flood of cheaper as well as luxury consumer imports to the Peruvian market. Domestic producers could not cope with this competition (which was attributed to a number of factors such as the sudden rise in costs of debt management). That led to increased pressure on the government and in 1984, they returned to the original tariffs from 1978 (Pastor and Wise, 1992, p. 89).

Conaghan, Malloy and Abugattas (1990, p. 4) ascribe this failure to tersely, but inconsistently applied neoliberal policy and gently criticize the steep tariff reductions without having reflected on the needs of manufacturers. An even greater factor that caused the failure of the policy seemed to be disputes in Belaúnde's government that could not reduce government spending to an acceptable level (Conaghan, Malloy and Abugattas, 1990, p. 16). 
Chile experienced many of the same difficulties as Peru, with the simple difference that the Chilean military regime weathered the turbulence following the transition, while the democratic government in Peru changed its policies in response to all hiccups and shocks caused by the changes in circumstances. This led to radical swings of economic policy from one extreme to the other, creating an unstable environment for investors and entrepreneurs.

The negative experience from 1983 and 1984 was therefore reflected in the 1985 elections, won by Alan Garcia whose policy turned from the previously neoliberal economic policies promoted by the IMF and the previous government, to more heterodox protectionist policies (Oxford Analytica Daily Brief Service, 1986). García's policy did not increase all tariffs, but also selectively reduced tariffs on imports of government-provided inputs for entrepreneurs such as gasoline and electricity. (Montalbano, 1986) However, even this policy was not successful and led to a collapse of foreign reserves in 1987 and consequently the utter collapse of this policy in 1988 (Pastor and Wise, 1992, p. 100-106).

The $10 \%$ tariff rate set in Chile in 1979 only lasted few years thanks to the uprising debt crisis linked to the increased level of international interest rates (Bulmer-Thomas, 2003, p. 205). There was an initial increase in tariff rates to $20 \%$ in 1983 as a part of measures responding to the crisis. This was followed a year later by an additional rate increase to $35 \%$. These increases; however, also had a negative impact on exports, which did not help counterbalance the balance of payments (Corbo, 1997, p. 76). The consequences of the crisis led the Ministry of Finance to suggest reintroducing the cascading tariff structure, assigning the task of determining which products were subject to higher or lower tariffs to the Manufacturers' Association itself. Unsurprisingly, this led to conflicting views, with each sector wishing to be the most protected from imports and while still being able to obtain the cheapest inputs. Given the profound contradictions on this issue, the Manufacturers' Association recommended to maintain the uniform tariff rate (Corbo, 1997, p. 76). Low uniform tariff rates caused an exit of inefficient companies which led to increased productivity (Pavcnik, 2000). The results of the study conducted by Nina Pavcnik indicate that the reallocation of resources and market share from inefficient to more efficient companies were significant for productivity enhancement. Between 1979 and 1986 overall productivity in Chilean manufacturing went up by $19 \%$, out of which $12.7 \%$ could be attributed to resources reallocation and the rest to improved productivity within Chilean firms (Pavcnik, 2000, p. 27).

This was a policy which, in the end, was consistent and fair, without specific, industry-based tariff privileges in place. As the crisis came to an end, the tariff rates were decreased again, first to $30 \%$ in 1985 and later down to $20 \%$. In 1988 they were decreased to $15 \%$ and in 1991 the democratically elected government reduced tariff rates to $11 \%$ (Corbo, 1997, p. 76).

\section{The 1990s and 2000s - The effects of international competition}

The adaptability and structural changes in the Chilean economy resulted in additional decreases of the average tariff rate. The more competitive market structure resulted in changes in the economic way of entrepreneurial thinking. The $11 \%$ tariff rates stayed until 1998. In 1999, rates deceased to $10 \%$, in 2000 to $9 \%$ and tariff rates stabilized in 2003 at $6 \%$ as the WTO's Tariff Analysis Online facility captures. Interestingly, the biggest pressure for tariff reduction came from entrepreneurs who perceived high tariff rates to be a barrier to exports, as seen in a proposal around 1997 to decrease tariffs from $11 \%$ to $7 \%$, which came directly from the Association of Entrepreneurs (Corbo, 1997, p. 76). 
The pressure from international financial institutions and the success of the Chilean economy which started to diverge from Peru in the 1990s (Figure 1) led to yet another Peruvian attempt to imitate the successful Chilean economic policy.

A neoliberal candidate, Alberto Fujimori, won the elections in 1991. As a result of his victory, his government introduced a series of neoliberal reforms, alongside a substantial reduction of tariffs in 1991 from maximum rates of $50 \%$ to $25 \%$ with averages dropping to $17 \%$. These changes helped lead Peru to long-term growth (OECD, 2010, p. 181) \& (Brooke, 1991).

Changes in the Peruvian government policies towards trade openness and economic crisis in the 1980s were reflected in labor productivity and output growth during the '70s, '80s and '90s (Table 1). Consistent economic policies carried out by the Chilean government and the reductions in tariffs led to more stable labor and output growth during this period, enabling them to withstand the crisis of the '80s better than Peru, whose labor productivity and output growth was much more volatile.

Table 1: Productivity, Output and Reform Indicators for Chile and Peru during 1970s- 90s

\begin{tabular}{|l|c|c|c|c|c|c|}
\hline & \multicolumn{2}{|c|}{ Labour productivity growth } & \multicolumn{2}{c|}{ Output growth } & \multicolumn{2}{c|}{ Commercial reform index } \\
\cline { 2 - 7 } & Chile & Peru & Chile & Peru & Chile & Peru \\
\hline $1970 \mathrm{~s}$ & $2.38 \%$ & $-0.01 \%$ & $5.08 \%$ & $3.76 \%$ & 0.623 & 0.507 \\
\hline $1980 \mathrm{~s}$ & $1.71 \%$ & $-3.98 \%$ & $4.41 \%$ & $0.24 \%$ & 0.936 & 0.623 \\
\hline $1990 \mathrm{~s}$ & $3.78 \%$ & $2.12 \%$ & $3.86 \%$ & $3.52 \%$ & 0.978 & 0.843 \\
\hline
\end{tabular}

Note: Commercial reform index represents the openness of the economy to trade. It ranges from 0 to 1 with 0 standing for the most protectionist approach and 1 for the most liberal.

Source: Paus, Reinhardt and Robinson (2003)

Peruvian rate reduction didn't stop in the '90s but continued until 2014 when Peru reached a $3.4 \%$ simple average tariff rate, a figure far below the Chilean average of $6 \%$ in the same year (World Trade Organisation Database, [No date]). Chile and Peru were not the only countries to show a reduction in applied tariffs, though. Between 2000 and 2012, the average applied tariff rate in Latin America dropped from $14.75 \%$ to $8.26 \%$ (Ilie \& Dumitru, 2014, p. 6). Reductions in tariffs and trade liberalization between the crisis year of 1980 and 2012 led, especially in case of Chile, to increased trade growth which had reached $66.8 \%$ of GDP. In Peru this growth was much smaller, likely due to inconsistent trade policy over the years, reaching only $28 \%$ of GDP, although still close to median in comparison to other LatinAmerican countries whilst Chilean was one of the highest (Ilie \& Dumitru, 2014, p. 4-5). 
Figure 2: Comparison of weighted tariff rates, Chile, Peru and the World average

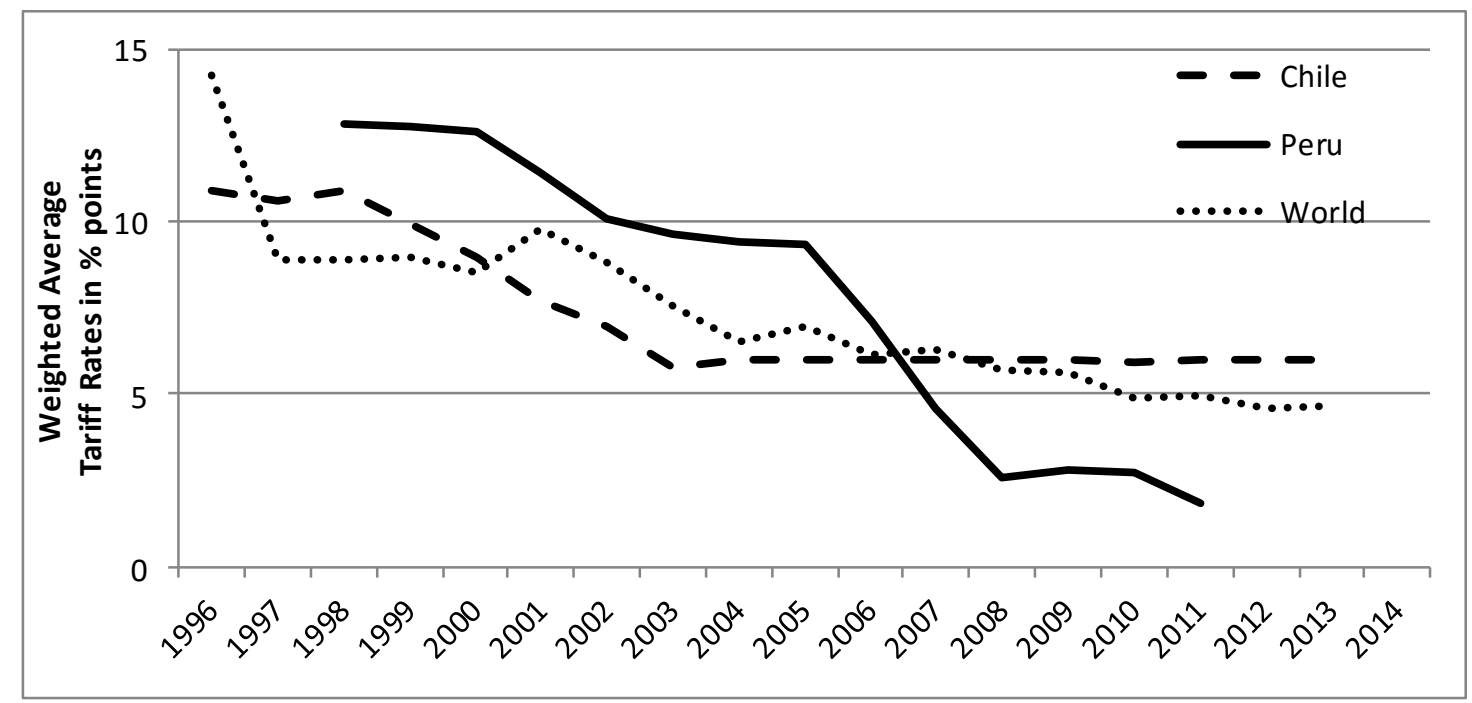

Source: World Bank Development Indicators: Weighted tariff rates [online] [accessed 4. December 2015]. Accessible from: data.worldbank.org/data-catalog/world-development-indicators

\section{Recent developments - the persistence of privileges in Peru}

So far not much attention has been paid to the bound tariffs that Chile and Peru apply. These are tariffs which countries are bound not to exceed in WTO negotiations. Applied tariffs are usually below the limit rate and if some of the countries would apply tariffs over the limit, other WTO members could protest and possibly achieve compensation by, for instance, increasing their own tariffs on imports from that particular country if an amicable solution cannot be reached. Border tariffs give businesses a level of certainty when predicting future development and enable them to plan their activities better. The greater the difference between the applied and bound rate, the higher level of uncertainty they are facing if they opt to export their products into the country (World bank, 2010).

Chile uses the same uniform principle for bound tariffs as it does for applied tariffs and approx. $98.7 \%$ of the products have the same maximum $25 \%$ bound rate. Exceptions can be found in certain agricultural products such as wheat or milk, covered by a $31.5 \%$ bound rate and sugar covered by $98 \%$ rate (World Trade Organization, 2007a). In comparison to Chile, Peru chose slightly higher border duties, with a majority of products at $30 \%$, only 5 percentage points higher than Chile. However, some agricultural products have a much higher threshold, which can reach 68\% (World Trade Organization, 2007b).

These high tariffs are partially "offset" by some zero bound rates on imports of, for instance, transistors, electric semiconductors, telephone sets, data-processing machines and calculating machines. Chile on the other hand does not apply any zero-rate boundary, not even on raw materials for which many industries prefer a zero tariff rate in order to obtain the lowest input costs (World Trade Organization, 2007a).

Approximately $99.4 \%$ of all items were covered under the $6 \%$ applied rate in 2015 (World Trade Organization, 2015a). Exceptions were printed books, cruise ships, tankers, fishing boats and certain transport vessels which had tariffs ranging between 5.3 to $2 \%$. Helicopters and aircraft weighing more than two tons, warships, nuclear reactors and armored vehicles were fully exempt from duty (World Trade Organization, 2007a). From this perspective Chile is a country that sets transparent and fair tariffs, giving importers from various sectors an equal chance to succeed in the Chilean market (and therefore create equal competitive 
pressure on all Chilean manufacturers). This uniform tariff policy was eventually approved by Chilean producers themselves, as mentioned in the previous section.

Peru, on the other hand, follows an entirely different structure of applied tariff rates and favors certain goods over others therefore exposing these to lower pressures from competitors abroad. Approximately $66.3 \%$ of items are fully exposed and have a $0 \%$ tariff rate, namely raw materials (such as calcium, uranium, copper, iron, aluminum, lead, natural gas and oil) as well as seafood, live animals, some vegetables (such as cucumbers), many chemicals, some medications, measuring instruments and apparatuses, hydraulic engines and turbines, and tires (World Trade Organization, 2015b).

For approximately $24 \%$ of the items, the rate was greater than $0 \%$ and lower than or equal to $6 \%$ (the 6\% rate was most common). This included certain types of food and agricultural products (selected items) and some meat, sophisticated instruments (such as cameras, watches), beer and tobacco products, cocoa powder, wooden furniture and automobiles (World Trade Organization, 2015b). On $10.5 \%$ of the items, Peru applies a tariff rate of $11 \%$ and on the remaining $0.2 \%$ of products an $8.5 \%$ rate. These two groups are primarily formed of beef, wool and cotton yarn textiles, clothing, coffee, wool (World Trade Organization, 2015b).

Peruvian tariff policy, therefore, unlike the Chilean, favors the importation of certain goods under a zero tariff policy while others are "discriminated against" by high tariffs. In 2013, for instance, this led to much more frequent importation of goods with zero or low rates and less goods with higher rates being imported. For comparison, the average tariff rate of items was $3.4 \%$, the average tariff rate applied to physically imported goods was half as high - only $1.8 \%$. The largest impact the cascading tariff structure had was on the imports of agricultural products where the weighted average tariff rate was 2.4 percentage points lower $(1.7 \%$ compared with the original $4.1 \%$ ). Industrial products differed by 1.5 percentage points, a simple average reaching 3.3\% and weighted 1.8\% (World Trade Organization Database, [No date]).). Imports can be divided into groups of similar products. For example, raw materials were imported almost duty-free and overall raw materials accounted for $39.2 \%$ of total imports (World Trade Organization, [No date]). Out of the group of machinery and transport vehicles more than $2 / 3$ were imported duty free. This group of products accounted for $35.8 \%$ of Peruvian imports. Machinery and transport vehicles combined with materials stand for $75 \%$ of imports which were imported into Peru largely duty-free. 
Table 2: Tariff and Imports: Materials, Machinery, Foodstuff (in \%, 2014)

\begin{tabular}{|c|c|c|c|c|c|c|}
\hline & \multicolumn{2}{|c|}{$\begin{array}{c}\text { MFN applied tariffs } \\
(\%)\end{array}$} & \multicolumn{2}{|c|}{$\begin{array}{l}\text { Duty free imports } \\
(\%)\end{array}$} & \multicolumn{2}{|c|}{$\begin{array}{c}\text { Share in overall } \\
\text { imports }(\%)\end{array}$} \\
\hline & Chile & Peru & Chile & Peru & Chile & Peru \\
\hline \multicolumn{5}{|l|}{ Materials } & 39.3 & 39.2 \\
\hline Petroleum & 6 & 0 & 0 & 100 & 17.2 & 15.1 \\
\hline Metals & 6 & 1.5 & 0 & 87.6 & 11.9 & 11.1 \\
\hline Chemicals & 6 & 2 & 0 & 60.7 & 10.2 & 13 \\
\hline \multicolumn{5}{|l|}{ Machinery/transport vehicles } & 37.1 & 35.8 \\
\hline Machines without electric power & 6 & 0.5 & 0 & 93.5 & 13.3 & 14.9 \\
\hline Machines with electric power & 6 & 2.1 & 0 & 75.7 & 9.2 & 11.9 \\
\hline Transport vehicles & 5.4 & 1 & 11.9 & 61.1 & 14.6 & 9 \\
\hline \multicolumn{5}{|l|}{$\begin{array}{r}\text { Foodstuff } \\
\end{array}$} & 4 & 8.2 \\
\hline Dairy products & 6 & 0 & 0 & 100 & 0.2 & 0.5 \\
\hline Cereals & 6 & 2.7 & 0 & 90.5 & 1.7 & 4.1 \\
\hline Oilseeds and oils & 6 & 2.4 & 0 & 91.5 & 1.1 & 2.7 \\
\hline Sugar & 6 & 0.9 & 0 & 67.8 & 0.5 & 0.4 \\
\hline Fish & 6 & 0.3 & 0 & 94.1 & 0.5 & 0.5 \\
\hline
\end{tabular}

Source: World Trade Organization Statistics Database on Tariff Profiles [online] [accessed 3. December 2015]. Accessible from: stat.wto.org/TariffProfile/WSDBTariffPFView.aspx?Language=E\&Country=PE,CL

Another less-represented group, which were imported in 2014 duty-free or with very low average tariffs, was foodstuff such as dairy products, cereals, oils, sugar and fish which accounted, overall, for $8.2 \%$ of imports with $90.5 \%$ of products imported duty free. Including machinery and materials, they account for $83.2 \%$ of imports with low or duty-free imports (World Trade Organization, [No date]).

Then there are areas that the Peruvian government protects, in some cases $0 \%$ of products imported are duty free, like beverages, tobacco, and cotton. Others had a higher tariff rate, for example, clothing had an $11 \%$ tariff rate, textiles averaged $8.4 \%$, while paper and wood averaged $4.4 \%$.

Apart from above mentioned products, coffee and tea were partially imported duty free to Peru (World Trade Organization, [No date]). Coffee was imported under fairly high tariff rates of $11 \%$ and $8.5 \%$ whilst tea was imported under the lower $6 \%$ tariff rate excluding extracts, which were brought in duty-free (World Trade Organization, 2015b). Attempts at protectionist rates can also be seen in fruits, vegetables and plants which were imported under a $5 \%$ average tariff rate. Livestock production had also relatively high tariff rates with (World Trade Organization, [No date]) beef standing out with a high $11 \%$ tariff rate (World Trade Organization, (2015b). 
Table 3: Tariff and Imports: Textile industry, Various (in \%, 2014)

\begin{tabular}{|c|c|c|c|c|c|c|}
\hline & \multicolumn{2}{|c|}{$\begin{array}{c}\text { MFN applied tariffs } \\
(\%)\end{array}$} & \multicolumn{2}{|c|}{$\begin{array}{l}\text { Duty free imports } \\
(\%)\end{array}$} & \multicolumn{2}{|c|}{$\begin{array}{c}\text { Share in overall } \\
\text { imports }(\%)\end{array}$} \\
\hline & Chile & Peru & Chile & Peru & Chile & Peru \\
\hline \multicolumn{7}{|c|}{ Textile industry } \\
\hline Cotton & 6 & 6.1 & 0 & 0 & 0 & 0.3 \\
\hline Textiles & 6 & 8.4 & 0 & 13.2 & 2.2 & 2.9 \\
\hline Clothing & 6 & 11 & 0 & 9 & 3.6 & 1.7 \\
\hline \multicolumn{7}{|l|}{ Various } \\
\hline Beverages \& tobacco & 6 & 6.1 & 0 & 0 & 0.6 & 0.5 \\
\hline Coffee and tea & 6 & 5.9 & 0 & 44.7 & 0.4 & 0.2 \\
\hline Fruits and vegetables & 6 & 5 & 0 & 6.7 & 0.7 & 0.7 \\
\hline Animal products & 6 & 5 & 0 & 28.7 & 1.5 & 0.3 \\
\hline Paper \& wood & 6 & 4.4 & 2.9 & 25.1 & 2.3 & 3.1 \\
\hline
\end{tabular}

Source: World Trade Organization Statistics Database on Tariff Profiles [online] [accessed 3. December 2015]. Accessible from: stat.wto.org/TariffProfile/WSDBTariffPFView.aspx?Language=E\&Country=PE,CL

However, in general, the groups of goods that Peru protects the most are clothing, textiles and cotton. All three are closely linked to the textile industry and are prime examples of the cascading tariff structure which is derived from the degree of procession of goods. These rates are also reflected in the total imports, especially in the prohibitive effect on imports of clothing compared to Chile. The reasons for the increased protection of the textile industry are jobs that the sector provides (Capechi, [No date], p. 2). Textiles in 2014 were one of the top manufactured goods exported (goods different from exports of metals and concentrates as well as agricultural products) and accounted for $20.5 \%$ (SUNAT, 2015).

Similarly, Peru protects its market against coffee and tea imports. Coffee benefits from different levels of protection depending on the concentration of caffeine and whether or not the coffee was roasted. If the coffee imported was roasted and decaffeinated, then a $6 \%$ rate was applied, if it contained caffeine, an $8.5 \%$ rate was applied. Unroasted coffee (with or without caffeine) faced an $11 \%$ tariff rate. The only product reducing the average group tariff burden were tea extracts which were imported duty-free (44.7\% of this group of imports) (World Trade Organization, [No date]) \& (World Trade Organization, 2015b).

However, overall coffee and tea imports only accounted for $0.2 \%$ of the total, compared to coffee exports which accounted for $14 \%$ of agricultural raw material exports and nearly $2 \%$ of total exports. As with the textile industry, this protective policy is likely to serve as a means of protecting jobs and consequently helping social stability (Capechi, [No date], p. 2).

Peru is much more inventive with their cascading tariff rates in comparison to Chile, which only gives lower rates $(5.4 \%)$ on means of transport imports (World Trade Organization, [No date]). The remaining rates are uniform and a reduction can only be achieved through preferential agreements.

\section{Conclusions}

We see that radical changes in both countries was thanks to a policy of total openness, the reduction of tariff rates and elimination of quotas and other barriers to foreign trade. Peru and Chile are the leaders in low tariff rates in South America, including the agricultural sector and are, to a large extent, comparable with those tariffs imposed in the USA and EU (Table 4). From a historical perspective, liberal changes are more effective if the political representation pursues consistent economic policy. It is also necessary for firms and economic agents in the market to see the benefits of free international trade and recognize that particular privileges 
can distort incentives and the distribution of profits in the national market economy. It seems that these privileges in international trade have to be in the form of selective norms rather than general rules which slow down the process of understanding the benefits of free trade.

Chile is the leading country in the region and likely has many followers in terms of economic policies. The historical analysis of economic policies in Peru showed us that drastic measures and forced economic policies were not something an elected executive power in Latin America can handle without difficulty. The best practices lie clearly in economic policy consistency which can be parametrically adjusted in case of economic or financial crises. A selective privilege makes it harder to change or adjust policies than a general rule (Chilean tariff rate). With selective privileges it is problematic for the economic agents to see the undistorted benefits of international competition and global markets i.e., the benefits of trade. In conclusion, we believe that there is a strong interdependence between privileges (a negative factor), the political stability and efficiency of economic policies.

\section{Acknowledgement}

This paper is supported by the research grant IGA 75/V ̌̌/MF/F5/115/2014.

\section{References}

[1] ANDERSEN, L. and R. BABULA, 2009. The Link between Openness and Long-Run Economic Growth. Journal of International Commerce and Economic [online]. 2, 31-50. [cit. 18. December 2015]. ISSN 2152-6877. Accessible from: wWw.usitc.gov/publications/332/journals/entire_journal_2009.pdf

[2] BAKEŠ, M., 1979. Teoretické otázky finančního práva. Prague: Charles University.

[3] BAKEŠ, M., 2012. Finanční právo. 6th ed. Prague: C. H. Beck. ISBN 978-80-7400-4407.

[4] BROOKE, J., 1991. Peru Struggles to Digest Free-market Reforms. New York Times [online]. 30. April 1991 [cit. 20. December 2015]. Accessible from: search.proquest.com/docview/428054058?accountid=17203

[5] BULMER-THOMAS, V., 2003. The Economic History of Latin America since Independence. 2nd ed. Cambridge: Cambridge University Press. ISBN 0-521-53274-4.

[6] CONAGHAN, C. M., J. M. MALlOY and L. A. ABUGATTAS, 1990. Business and the "Boys": The Politics of Neoliberalism in the Central Andes. Latin American Research Review [online]. 25(2), 3-30 [cit. 18. December 2015]. ISSN 0023-8791. Accessible from: www.jstor.org/stable/2503778

[7] Council Regulation (EEC) No 2913/92 of 12 October 1992 establishing the Community Customs Code. Council of the European Union [online]. [cit. 2. December 2015]. Accessible from: content/EN/ALL/?uri=CELEX\%3A31992R2913

eur-lex.europa.eu/legal-

[8] CORBO, V., 1997. Trade Reform and Uniform Import Tariffs: The Chilean Experience. The American Economic Review [online]. 87(2), 73-77 [cit. 18. December 2015]. ISSN 0002-8282. Accessible from: www.jstor.org/stable/2950887

[9] EDWARDS S., 2009. Latin America's Decline: A Long Historical View [online]. NBER Working Paper 15171. [cit. 18. December 2015]. Accessible from: www.nber.org/papers/w15171 
[10] ILIE, A. G. and D. DUMITRU, 2014. Latin America and the Challenges of Globalisation. Journal of Eastern Europe Research in Business and Economics [online]. 2014, 1-15 [cit. 18. December 2015]. ISSN 2169-0367. Accessible from www.ibimapublishing.com/journals/JEERBE/2014/211047/211047.pdf

[11] KLABOUCHOVÁ, I., 1995. Cla a pưvod zboží: Praktický průvodce celním systémem České republiky. 1st ed. Prague: Polygon. ISBN 80-901778-6-7.

[12] LOVE, P. and R. LATTIMORE, 2009. International trade: Free, Fair and Open? Paris: OECD. ISBN 978-92-64-06024-1.

[13] MATOUŠEK, P. and L. SABELOVÁ, 2007. Clo. Praha: ASPI Wolters Kluwer. ISBN 978-80-7357-263-1.

[14] MELlER, P., 1992. A Review of Chilean Privatization Experience. Texas Papers on Latin America [online]. [cit. 18. December 2015]. ISSN 0892-3507. Accessible from: lanic.utexas.edu/project/etext/llilas/tpla/9306.pdf

[15] MONFORT, B., 2008, May. Chile: Trade Performance, Trade Liberalization, and Competitiveness [online]. IMF Working Paper 08/128. [cit. 3. December 2015]. ISSN 1018-5941. Accessible from: www.imf.org/external/pubs/ft/wp/2008/wp08128.pdf

[16] MONTALBANO, W. D., 1986. Peru's Garcia: Leftist, Supply Sider Brash Iconoclast Embraces Reforms, Takes on the IMF. Los Angeles Times [online]. 3. March 1986 [cit. 18. December 2015]. Accessible from: search.proquest.com/docview/ 292259616 ? accountid $=17203$

[17] Nález Ústavního soudu p.zn. III. ÚS 741/06 I. K výkladu pojmu globálního zajištění celního dluhu (globální celní záruky). The Constitutional court of the Czech Republic [online]. [cit. 16. December 2015]. Accessible from: nalus.usoud.cz/Search/GetText.aspx?sz=1-643-06_1

[18] OECD, 2010. Country Review: Peru. OECD Journal of Competition Law and Policy [online]. 11(1), 177-230 [cit. 18. December 2015]. ISSN 1609-7521. Accessible from: search.proquest.com/docview/744488256? accountid=17203

[19] OXFORD ANALYTICA DAILY BRIEF SERVICE, 1986. PERU: Politics. President Garcia's First 6 Months in Power. Oxford Analytica Daily Brief [online]. 03. February 1986 [cit. 18. December 2015]. Accessible from: search.proquest.com/docview/ 192414127 ? accountid=17203

[20] PASTOR, M. and C. WISE, 1992. Peruvian Economic Policy in the 1980s: From Orthodoxy to Heterodoxy and Back. Latin American Research Review [online]. 27(2), 83-117 [cit. 18. December 2015]. ISSN 1542-4278. Accessible from: Www.jstor.org/stable/2503750?seq=1\#page_scan_tab_contents

[21] PAUS, E., N. REINHARDT and M. ROBINSON, 2003. Trade Liberalization and Productivity Growth in Latin American Manufacturing, 1970-98. Journal of Policy Reform [online]. 6(1), 1-15 [cit. 11. December 2015]. ISSN 1542-4278. Accessible from: www.mtholyoke.edu/ mirobins/GPRE031005.pdf

[22] PAVCNIK, N., 2000. Trade liberalization, Exit and Productivity Improvements: Evidence from Chilean Plants [online]. NBER Working Paper 7852. [cit. 14. December 2015]. Accessible from: www.nber.org/papers /w7852.pdf

[23] PRZEWORSKI, A. and C. CURVALE, 2005. Does Politics Explain the Economic Gap between the United States and Latin America? Department of Politics: New York 
University [online]. 14. December 2005 [cit. 26. November 2015]. Accessible from: politics.as.nyu.edu/docs/IO/2800/ba_gap.pdf

[24] Resumen ejecutivo. Tratado de Libre Comercio entre Perú y China. CAPECHI [online]. Accessible from: www.capechi.org.pe/pdfs/informes_finales_tlc_peru-china.pdf

[25] SUNAT, 2015. Exportación definitiva. Cuadro Nº18: Principales Subpartidas Nacionales según Sector Económico. Estadísticas de comercio exterior [online]. [cit. 26. November 2015]. Accessible from: www.sunat.gob.pe/estad-comExt/modelo_web/Bol2014.htm

[26] ŠTĚRBOVÁ L., I. ČERNÁ, R. ČAJKA and I. BOLOTOV, 2013. Mezinárodní obchod ve světové krizi 21. století. Praha: Grada Publishing. ISBN 978-80-247-4694-4.

[27] WORLD BANK, 2010. Types of Tariffs [online]. [cit. 8. December 2015]. Accessible from:

wits.worldbank.org/wits/wits/witshelp/Content/Data_Retrieval/P/Intro/C2.Types_of_Tari ffs.htm

[28] WORLD TRADE ORGANISATION, 2007a. Bound Tariffs at HS 6-digit Subheading Level. Goods Schedules and Tariff Data. Chile [online]. [cit. 8. December 2015]. Accessible from: stat.wto.org/idbdata/cts_chl_e.zip

[29] WORLD TRADE ORGANISATION, 2007b. Bound Tariffs at HS 6-digit Subheading Level. Goods Schedules and Tariff Data. Peru [online]. [cit. 8. December 2015]. Accessible from: stat.wto.org/idbdata/cts_per_e.zip

[30] WORLD TRADE ORGANISATION, 2015a. Latest Available MFN Applied Tariffs at HS 6-digit Subheading Level. Goods Schedules and Tariff Data. Chile [online]. [cit. 8. December 2015]. Accessible from: stat.wto.org/idbdata/idb_chl_last_e.zip

[31] WORLD TRADE ORGANISATION, 2015b. Latest Available MFN Applied Tariffs at HS 6-it Subheading Level. Goods Schedules and Tariff Data. Peru [online]. [cit. 3. December 2015]. Accessible from: stat.wto.org/idbdata/idb_per_last_e.zip

[32] WORLD TRADE ORGANISATION. Part A.1. Tariffs and Imports: Summary and Duty Ranges. Chile \& Peru [online]. [cit. 11. December 2015]. Accessible from: stat.wto.org/TariffProfile/WSDBTariffPFView.aspx?Language=E\&Country=PE,CL

[33] WORLD TRADE ORGANISATION. Tariffs and Imports: Summary and Duty Ranges. World Trade Organization Statistics Database [online]. [cit. 2. December 2015]. Accessible from: stat.wto.org/TariffProfile/WSDBTariffPFReporter.aspx ?Language=E

[34] ŽÍDEK, L., 2005. Chilean Economy under Pinochet. Acta univ. agric. et silvic Mendel. Brun. [online]. LIII(3), 225-240 [cit. 8. December 2015]. Accessible from: acta.mendelu.cz/media/pdf/actaun_2005053030225.pdf 


\section{Appendix A}

Table 4: Comparison of tariffs in South America and the World in 2014

\begin{tabular}{|l|l|l|l|}
\hline \multicolumn{1}{|c|}{ Country } & \multicolumn{1}{c|}{$\begin{array}{c}\text { Mean } \\
\text { value }\end{array}$} & \multicolumn{1}{c|}{$\begin{array}{c}\text { Agricultural } \\
\text { products }\end{array}$} & $\begin{array}{c}\text { Non Agricultural } \\
\text { products }\end{array}$ \\
\hline European Union & 5.3 & 12.2 & 4.2 \\
\hline Japan & 4.2 & 14.3 & 2.5 \\
\hline United States & 3.5 & 5.1 & 3.2 \\
\hline Peru & 3.4 & 4.1 & 3.3 \\
\hline Chile & 6.0 & 6.0 & 6.0 \\
\hline Colombia & 5.8 & 14.9 & 4.2 \\
\hline Paraguay & 10.0 & 10.0 & 10.1 \\
\hline Ecuador & 11.9 & 18.3 & 10.9 \\
\hline Suriname & 10.4 & 18.4 & 9.2 \\
\hline Uruguay & 10.5 & 9.9 & 10.6 \\
\hline Bolivia & 11.6 & 12.3 & 11.5 \\
\hline Venezuela & 12.9 & 11.9 & 13.0 \\
\hline Argentina & 13.6 & 10.4 & 14.2 \\
\hline Brazil & 13.5 & 10.2 & 14.1 \\
\hline
\end{tabular}

Source: World Trade Organization Statistics Database on Tariff Profiles [online] [accessed 3. December 2015]. Accessible from: stat.wto.org/TariffProfile/WSDBTariffPFReporter.aspx?Language=E; World Bank National Accounts Data and OECD National Accounts Data Files: GDP per capita [online] [accessed 3.December 2015]. Accessible from: data.worldbank.org/indicator/NY.GDP.PCAP.KD 